\section{GOITER-RELATED PREDICTORS OF DIFFICULT INTUBATION: CASE REPORT}

\author{
Suzana El Farra ${ }^{1}$, Dragana Radovanović ${ }^{1,2}$, \\ Aleksandar Stokić ${ }^{1}$, Duško Manić ${ }^{1}$ \\ ${ }^{1}$ Oncology Institute of Vojvodina, Department of anesthesiology, \\ intensive therapy and care, Sremska Kamenica, Serbia \\ ${ }^{2}$ University of Novi Sad, Medical faculty, Novi Sad, Serbia
}

\section{Abstract}

Introduction: Preoperative examination and recognizing the risk factors for a difficult airway gives us the time for optimal preparation for difficult airway management. For goiter patients, in addition to the standard risk factors, there are goiter-related factors that may address to suspect of difficult intubation. Case report: Through this case report we summarize the presentation, airway examination and management of a patient with huge goiter. About 25-years earlier he noticed a swelling on the neck which increased in size progressively. Over the years he developed compressive symptoms, such as dysphagia, hoarseness and change in voice quality. All classical risk factors for difficult intubation, as well as goiter-related factors, were preoperatively evaluated. The neck circumference, the left displacement of the larynx and the radiological findings all pointed to a possible difficulty in airway management. The plan was to perform a direct laryngoscopy using a video-laryngoscope, without using a muscle relaxant, whereas the alternate plan was to use a flexible fibreoptic bronchoscope. The patient's airway was anesthetized with lignocaine spray into the laryngo-pharynx 30 minutes and 10 minutes before intubation. Oxygen was administered via facemask. The nasal catheter was placed to provide apnoic oxygenation during laryngoscopy and intubation. After induction of anesthesia a smooth video laryngoscopy was performed without using a muscle relaxant. A reinforced endotracheal tube with an intubating stylet was inserted without any difficulties in passing and placing the tube. Conclusion: Careful planning and detailed preoperative preparation are of crucial importance for a safe intraoperative and postoperative outcome in thyroid patients.

Key words: goiter; difficult intubation; airway management; video-laryngoscopy

Corresponding author: Suzana El Farra, Department of anesthesiology, intensive therapy and care, Oncology Institute of Vojvodina, Put doktora Goldmana 4, 21204 Sremska Kamenica, Telephone: 0640277893, E-mail: andric.d.suzana@gmail.com

\section{STRUMA KAO PREDIKTOR OTEŽANE INTUBACIJE: PRIKAZ SLUČAJA}

\author{
Suzana El Farra ${ }^{1}$, Dragana Radovanović ${ }^{1,2}$, \\ Aleksandar Stokić ${ }^{1}$, Duško Manić ${ }^{1}$ \\ ${ }^{1}$ Institut za onkologiju Vojvodine, Odeljenje anestezije, intenzivne \\ terapije i nege, Sremska Kamenica, Srbija \\ ${ }^{2}$ Univerzitet u Novom Sadu, Medicinski fakultet, Novi Sad, Srbija
}

\section{Sažetak}

Uvod: Preoperativni pregled i uočavanje prisustva faktora rizika pružaju mogućnost adekvatne pripreme za obezbedivanje otežanog disajnog puta. Kod pacijenata sa uvećanom štitastom žlezdom, pored standardnih, potrebno je uzeti u obzir i faktore povezane sa strumom, koji mogu da ukažu na mogućnost otežane intubacije. Prikaz slučaja: Kroz ovaj prikaz predstavićemo preoperativni pregled, procenu i obezbeđivanje disajnog puta pacijenta sa ogromnom strumom. Pacijent je pre 25 godina primetio uvećanje žlezde koje se progresivno povećavalo. Tokom godina su se razvili znaci kompresije u vidu disfagije, promuklosti i promene kvaliteta glasa. Preoperativno su procenjeni svi klasični, kao i sa strumom povezani prediktori otežane intubacije. Uvećan obim vrata, potisnutost larinksa u levo, kao i radiološke pretrage, ukazivali su na moguće poteškoće u obezbeđivanju disajnog puta. Plan je bio da se bez upotrebe mišićnog relaksanta izvede direktna laringoskopija upotrebom video-laringoskopa, dok je alternativni plan bio upotreba fleksibilnog fiberoptičkog bronhoskopa. Pacijentu je disajni put anesteziran lidokainskim sprejom 30 i 10 minuta pre intubacije. Preoksigenacija je sprovedena putem maske za lice. Postavljen je nazalni kateter, kako bi se omogućila $i$ apnoična oksigenacija tokom laringoskopije i intubacije. Nakon uvoda u anesteziju, izvedena je video-laringoskopija bez upotrebe mišićnog relaksanta. Uz upotrebu intubacionog stajleta, armirani endotrahealni tubus je plasiran bez poteškoća. Zaključak: Pažljivo planiranje i detaljna preoperativna priprema su od ključnog značaja za intraoperativnu i postoperativnu sigurnost pacijenata sa strumom.

Ključne reči: struma; otežana intubacija; obezbeđivanje disajnog puta; video-laringoskopija

Autor za korespondenciju: Suzana El Farra, Odeljenje anestezije, intenzivne terapije i nege, Institut za onkologiju Vojvodine, Put doktora Goldmana 4, 21204 Sremska Kamenica, Telefon: 0640277893, E-mail: andric.d.suzana@gmail.com 


\section{Introduction}

$\mathrm{M}$ aintaining a patient's airway is essential for adequate oxygenation and ventilation and failure to obtain such a goal, even for a brief period of time, can be life threatening. 1 Thyroid swelling or goiter has been considered a risk factor for difficult direct laryngoscopy, intubation and respiratory complications. Therefore, preoperative detection of any difficulty in maintaining the airway or intubation during the induction of anesthesia and airway control after thyroid surgery is essential1,2. For goiter patients, in addition to the standard risk factors, there are goiter-related factors that may address to suspect of difficult intubation 3 .

Through this case report we summarize the presentation, airway examination and management of a patient with huge goiter.

\section{Case report}

A 59 years old male patient, ASA (American Society of Anesthesiologists) physical status grade I, with BMI $32 \mathrm{~kg} / \mathrm{m}^{2}$, presented with a huge goiter. About 25-years earlier he noticed a swelling on the neck which increased in size progressively. Over the years he developed compressive symptoms, such as dysphagia, hoarseness and change in voice quality. He had no concomitant morbidities, no past surgical or medical history, and no relevant family medical history.

The patient was scheduled for a near total thyroidectomy. The procedure was explained to the patient and a written consent was obtained.

Routine preoperative tests were performed. A thyroid hormone profile confirmed the eu-thyroideal status of the patient. All hematological and biochemical tests were within normal limits.

The patient was conscious and cooperative. He was hemodynamically stable. His physical examination was unremarkable except for a prominent anterior neck swelling, which is shown in Figure 1. On palpation, it was firm, immobile, and nodular. The swelling did not move with deglutition.

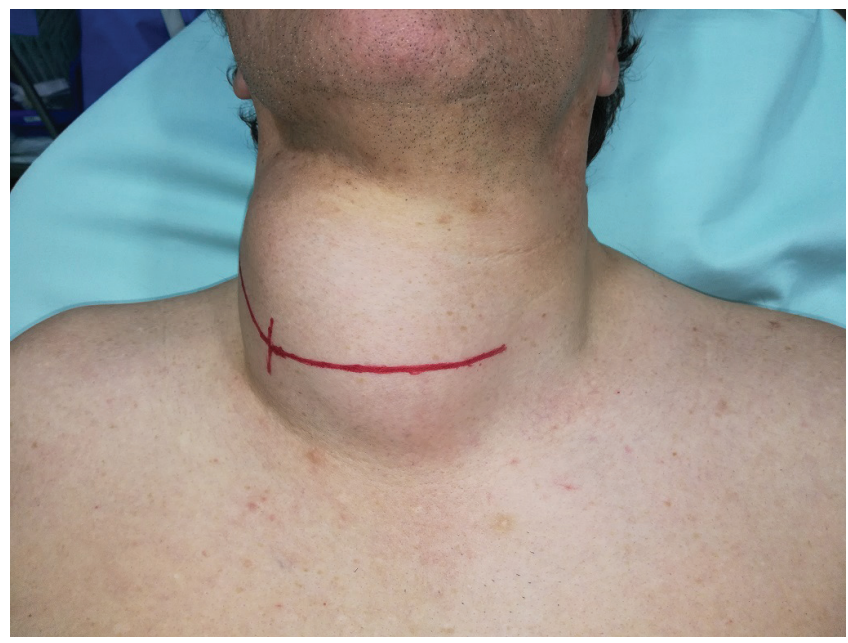

Figure 1. Prominent anterior neck swelling

Airway examination showed adequate mouth opening, with inter-incisor distance $>5 \mathrm{~cm}$. Mallampati score was class I. Dental examination showed an instability of the dental bridge, which required extra caution during intubation. Jaw protrusion and upper lip bite tests were normal. There was no restriction in temporo-mandibular joint movement. The mandibulo-hyoid distance was $5 \mathrm{~cm}$. The thyro-mental distance was difficult to measure, because of the left displacement of the larynx (Figure 2). The sterno-mental distance was $22 \mathrm{~cm}$. Flexion and extension of the head and neck was normal - above $90^{\circ}$. The neck circumference measured at the level of the thyroid cartilage was $52 \mathrm{~cm}$, while at the level of the maximal bulge of the gland it was $55 \mathrm{~cm}$ (Figure 3).

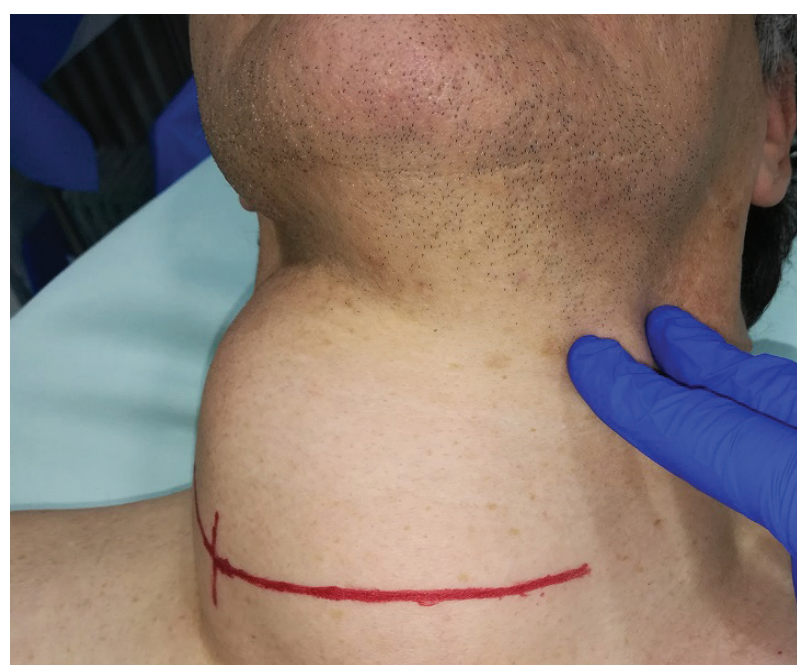

Figure 2. Left displacement of the larynx 

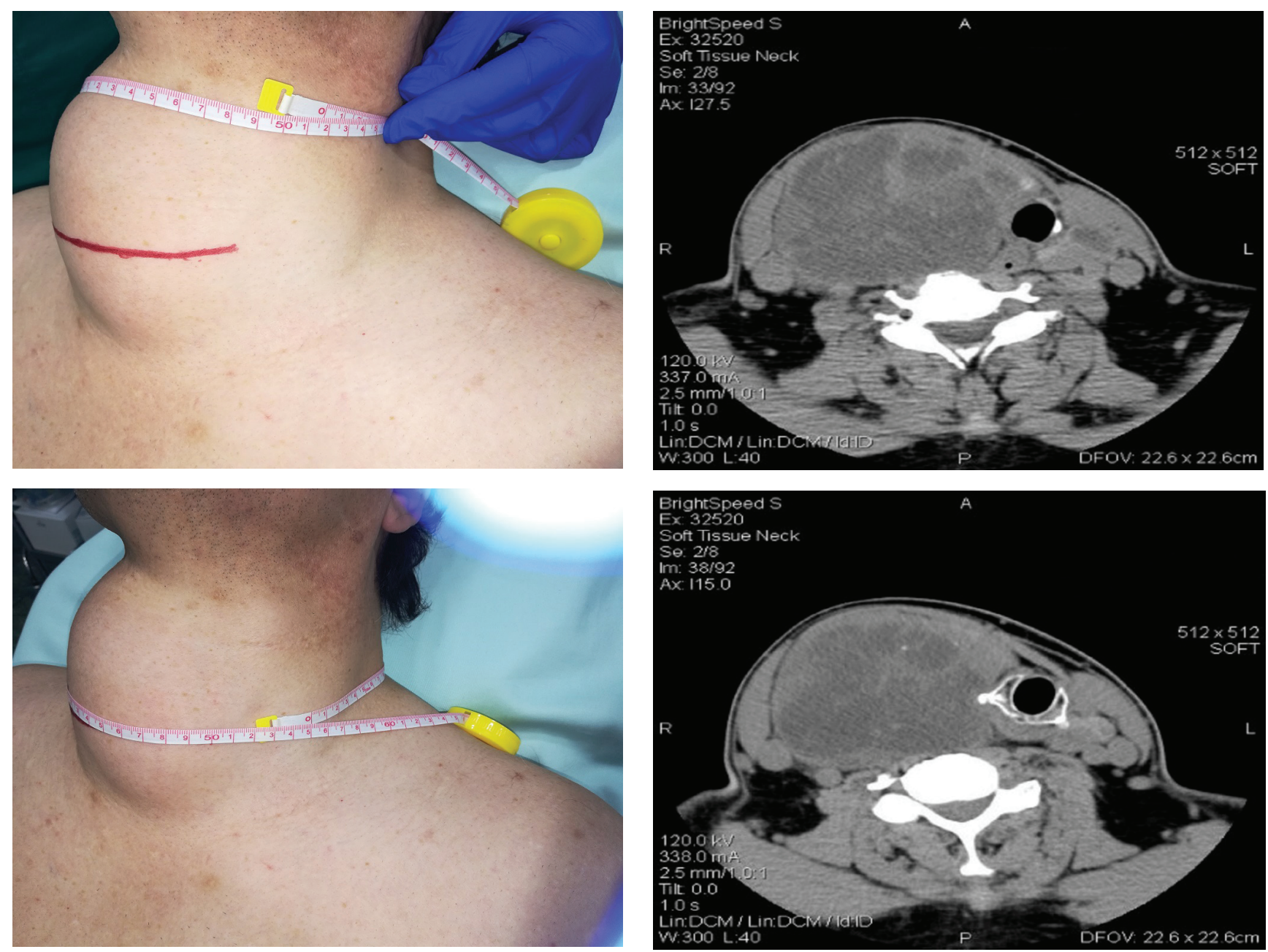

Figure 3. Neck circumference measured at the level of the thyroid cartilage and at the level of the maximal bulge of the gland

The indirect mirror laryngoscopy revealed no restriction of vocal cord mobility, but showed that the whole larynx was displaced to the left.

The ultrasonography showed a multinodular nature and enlargement of the gland, particularly the isthmus and right lobe. X-ray showed leftsided deviation of trachea. CT-scan showed a huge multinodular goiter. The right lobe was 112 x 84 x $72 \mathrm{~mm}$ in size, while the left lobe was 63 x 27 x $25 \mathrm{~mm}$. Consequently, the enlarged lobes had significantly displaced the hyoid bone, trachea and other structures of the neck (Figure 4).

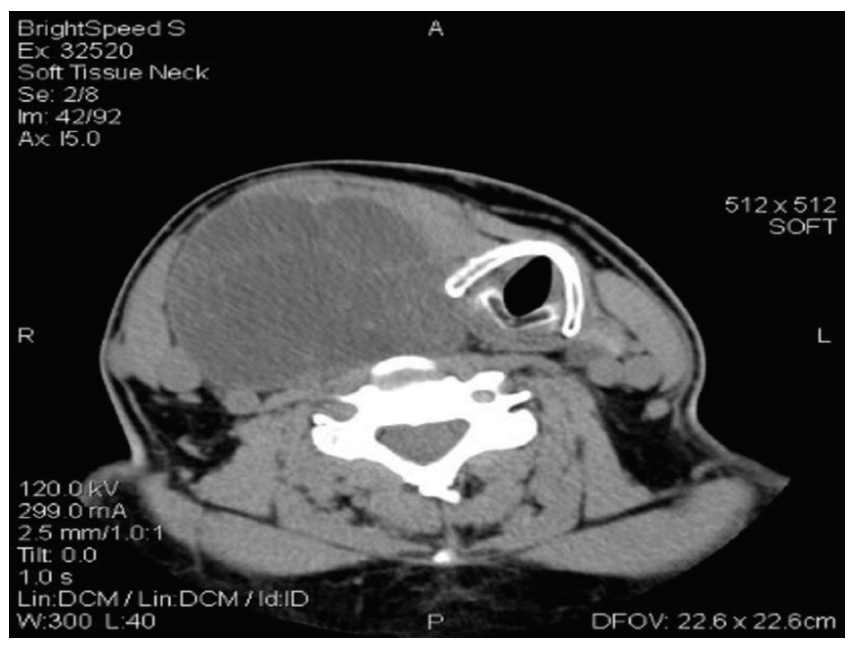

Figure 4. CT-scan showing displacement of the hyoid bone, trachea and other structures

After securing an intravenous line with $17 \mathrm{G}$ cannula in the left upper limb, Midazolam $2.5 \mathrm{mg}$ was administered as a premedication. Standard monitors (electrocardiography, pulse oximeter, non-invasive blood pressure) were attached and the baseline vitals recorded.

The plan was to perform a direct laryngoscopy using video-laryngoscope and to try securing 
the airway, whereas the alternate plan was to use a flexible fibreoptic bronchoscope in awake spontaneously breathing patient. The difficult airway management cart was kept ready.

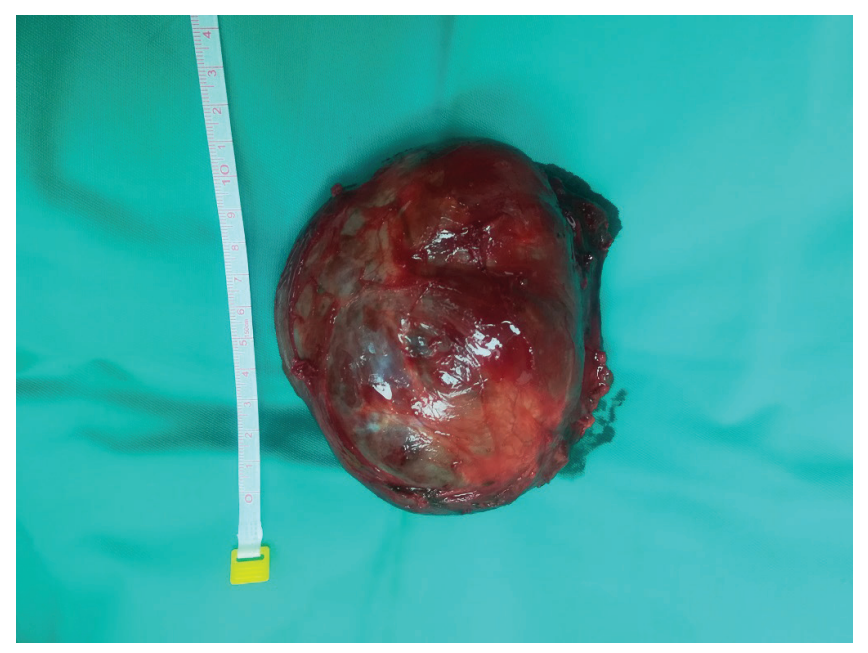

Figure 5. Resection of huge right lobe

The patient's airway was anesthetized with $10 \%$ lignocaine spray into the laryngo-pharynx $30 \mathrm{~min}$ utes and 10 minutes before intubation. Each activation of the metered dose valve delivers $0.1 \mathrm{ml}$ which contains $10 \mathrm{mg}$ lignocaine. The used lignocaine dose did not exceed the maximum dose.

The patient was placed in a sniffing position. Preoxygenation with 100\% oxygen was performed via standard facemask. The nasal catheter was placed to provide apnoic oxygenation during laryngoscopy and intubation.

A few minutes before intubation, Fentanyl 50 mcg and Midazolam $5 \mathrm{mg}$ were administered. After a bolus of $150 \mathrm{mg}$ of Propofol a smooth video-laryngoscopy was performed without using a muscle relaxant.

The video-laryngoscopy showed left displacement of the larynx. After external laryngeal manipulation, which improved the laryngeal view, a reinforced endotracheal tube with an intubating stylet was inserted. There were no difficulties in passing and placing the endotracheal tube.

The breathing circuit was attached, and the tube placement was confirmed with normal and repeated $\mathrm{CO} 2$ waves. The endotracheal tube was firmly secured and anesthesia was maintained with $\mathrm{O} 2$, N2O, Sevoflurane, Rocuronium and Fentanyl. The patient remained hemodynamically stable throughout the whole procedure.
The thyroidectomy, although being technically difficult and demanding, because of the size of goiter (Figure 5), was carried out without any complications.

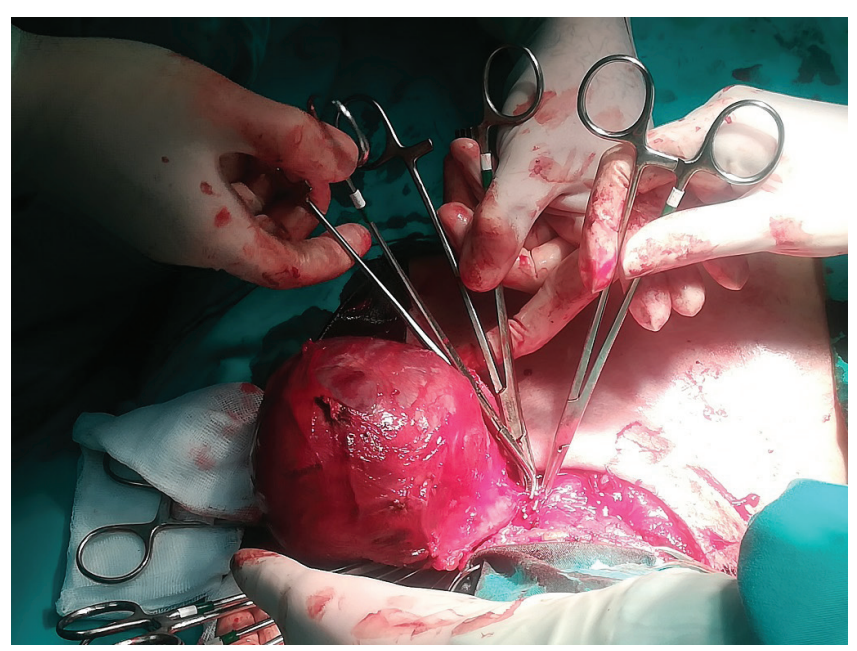

At the end of the surgery, the patient's muscle relaxation was antagonized using $2.5 \mathrm{mg}$ of Neostigmine and $1 \mathrm{mg}$ of Atropine. Before extubation, the cuff leak test was performed to avoid airway obstruction secondary to tracheomalacia. As there was no collapse of the tracheal rings, the patient was successfully extubated. The patient's condition was postoperatively monitored in the intensive care unit. The difficult airway management cart was kept ready.

\section{Discussion}

Problems with airway management are the main concern of any anesthesiologist when intubating a patient with goiter 2,3 . Preoperative examination and recognizing the risk factors for a difficult airway gives us the time for optimal preparation, proper selection of equipment and personnel experienced in difficult airway management 1 .

Thyroid tissue overgrowth may lead to changes in the airway, consequently causing difficulties in intubation procedures. Previously published studies have reported various results and various risk factors for intubating difficulties associated with thyroid gland surgery 4 .

Thyroidectomy due to huge goiter with a compromised airway is usually associated with difficult 
airway management at the time of induction of anesthesia, during and after surgery 5 . This requires careful pre anesthetic assessment of the patient, disease control status, airway assessment, blood analysis and imaging studies6.

Various noninvasive clinical tests can be performed to predict difficult airway maintenance, but there is no precise or ideal scoring system that predicts difficult ventilation, laryngoscopy or intubation. Despite numerous studies which included various risk factors, false positive results have been reported, but more importantly, there are false negative values that can mislead anesthesiologists. Increasing number of risk factors analyzed leads to higher specificity, but unfortunately, they are still not sensitive enough7.

In our case, all classical risk factors for difficult intubation, as well as goiter-related factors, were preoperatively evaluated. The neck circumference, the left displacement of the larynx and the radiological findings all pointed to a possible difficulty in airway management.

In huge goiter patients, induction of general anesthesia could be risky because it may precipitate complete airway closure and make facemask ventilation and tracheal intubation impossible due to chronic pressure8.

Preoperative anticipation of difficult intubation and evaluation of risk factors for difficult intubation is of vital importance so that alternative approach is kept ready to avoid any complication during intubation9.

Awake fibreoptic intubation is widely advocated for the management of the known or anticipated difficult airway 10 . It is recommended that an initial fibreoptic bronchoscopy to be done to define the extension of the thyroid mass and to rule out obstruction of the airway11. However, fibreoptic intubation can be a challenging technique, continuous practice is needed to maintain the skill and usually takes a considerable amount of time to be performed. All these factors have led to the underuse of fibreoptic intubation by many anesthetists 10. A good alternative for difficult intubation is the video-laryngoscope 12 . Video-laryngoscopes are increasing in popularity and are slowly becoming the preferred tool for the management of the difficult airway. There are some potential advantages of video-laryngoscopes over fibreoptic bronchoscopes. They seem to be easier and quicker to use and provide a wider view of the airway, which results in a better view of nearby structures 10,12 .

In our case, the airway examination and the radiological findings showed the presence of a huge goiter which displaced the larynx and trachea, without tracheal narrowing. The patient had no breathing difficulties and he tolerated the supine position. Considering the airway assessment, the expertise and experience of the anesthetists, as well as the patient's cooperability and consent, the decision was to perform a video-laryngoscopy without using a muscle relaxant. The use of a flexible fibreoptic bronchoscopy in the awake spontaneously breathing patient was kept as an alternative plan.

Another major concern in these patients is tracheomalacia, which can complicate both intubation and extubation. Pressure on the trachea exerted by the neck mass can cause necrosis to parts of the tracheal wall, which can lead to complete collapse of the airway8. Extubation and the immediate postoperative period are certainly high-risk situations in all cases of difficult intubation. As suggested in many case reports and recommendations, the safest way to proceed while suspecting a difficult extubation is the "protected" extubation. Evaluation of airway patency after tube removal remains difficult to perform. No perfect tool actually exists to predict or to early detect an airway obstruction 13. A meta-analysis suggested that a cuff leak test appears to have excellent specificity and moderate sensitivity. Cuff leak test works better for ruling in than ruling out the post-extubation airway obstruction. Given the considerable burden associated with extubation failure, it is useful and reasonable for a cuff leak test to rule in high-risk patients ${ }^{14}$.

In our case, cuff leak test was performed to rule out tracheomalacia. The patient was successfully extubated and his condition was postoperatively monitored in the intensive care unit.

Definition of a safe time window after extubation is particularly difficult. The only valuable option remains close observation of the patient, but first of all being aware of potential life-threatening complications that might occur at any time 13 .

Although several studies have tried to predict the occurrence of a difficult airway with the use of a single risk factor or risk factors used in combination, the ideal indicator or set of indicators remains elusive 15 . 


\section{Conclusion}

"To be forewarned is to be forearmed". Careful planning and detailed preoperative preparation are of crucial importance for a safe intraoperative and postoperative outcome in thyroid patients.

\section{References}

1. Gupta S, Sharma R, Jain D. Airway assessment: predictors of difficult airway. Indian J. Anaesth. 2005; 49(4):257-262.

2. Tripathi M. Goiter and airway control. World Journal of Endocrine Surgery. 2010; 2(1):33-40.

3. Olusomi BB, Aliy SZ, Babajide AM, et all. Goiter-related factors for predicting difficult intubation in patients scheduled for thyroidectomy in a Resource-Challenged Health Institution in North Central Nigeria. Ethiopian Journal of Health Sciences. 2018; 28(2):169-176.

4. Tutuncu AC, Erbabacan E, Teksoz S, et all. The assessment of risk factors for difficult intubation in thyroid patients. World J Surg. 2018; 42(6):1748-1753.

5. Ahmed S, Zaeem K, Kashif S, Uddin SS. Anesthetic management of huge multinodular goiter with compromised airway. Editorial Advisory Board Chairman. 2016; 66:275.

6. Naik S, Ranjan N, D'Souza O. Case report and review of literature on anaesthesia management of massive colloid multinodular goitre. International Journal of Scientific Research. 2018; 7(2).
7. Kalezić N, Milosavljević R, Paunović I, et al. The incidence of difficult intubation in 2000 patients undergoing thyroid surgery: A single center experience. Vojnosanitetski pregled. 2009; 66(5):377-382.

8. Shaikh SI, Atlapure BB. Airway challenges in thyroid surgery. Karnataka Anaesthesia Journal. 2015; 1(1):28.

9. Shah PN, Gupta G. Prediction of difficult endotracheal intubation in thyroid surgery. International Journal of Anesthesiology Research. 2014; 2(1):6-10.

10. Alhomary M, Ramadan E, Curran E, Walsh SR. Videolaryngoscopy vs. fibreoptic bronchoscopy for awake tracheal intubation: a systematic review and meta-analysis. Anaesthesia. 2018.

11. Ambreesha M, Upadhya M, Ranjan RK, Kamath S. Preoperative fibreoptic endoscopy for management of airway in huge thyroid. Indian J Anaesth. 2003; 47:489-90.

12. Salama AK, Hemy A, Raouf A, Saleh N, Rady S. C-MAC Video laryngoscopy versus flexible fiberoptic laryngoscopy in patients with anticipated difficult airway: a randomized controlled trial. J Anesth Pati Care. 2015; 1(1):101.

13. Sorbello M, Frova G. When the end is really the end? The extubation in the difficult airway patient. Minerva Anestesiol. 2013; 79(2):194-199.

14. Kuriyama A, Jackson J. 19: Cuff leak test to predict post-extubation airway obstruction in adults a meta-analysis. Critical Care Medicine. 2018; 46(1):10.

15. Garg R, Dua CK. Identification of ideal preoperative predictors for difficult intubation. Karnataka Anaesthesia Journal. 2015; 1(4):174. 